\title{
Erkek infertilitesinde tamamlayıcı tıp uygulamaları: Kanıt düzeyi nedir?
}

\author{
Usage of complementary medicine in male infertility: \\ What is the level of evidence?
}

\author{
Coșkun Kaçağan®, Halil Lütfi Canatఠ
}

\section{öz}

Erkek faktörüne bağlı infertilitelerin yaklaşık yarısının etiyolojisi hala tam olarak aydınlatılamamıştır. İdiyopatik infertilitenin tedavisinde modern tıbbın tedavilerine ek olarak tamamlayıcı tıp seçenekleri de artık günümüzde oldukça sık tercih edilmektedir. Tamamlayıcı tıbbın son zamanlarda modern tıp alanında kullanımının artmasıyla bitkisel kökenli bu ajanlar, hastalar tarafindan da sıkça tercih edilmektedir. Tamamlayıcı tıp tedavilerinde gebelik ve canlı doğum oranlarıla ilgili henüz yeterli kanıt olmamasına rağmen yardımcı üreme yöntemlerinin bir parçası olarak subfertil erkeklere etkinliği kanıtlanmış antioksidanlar ve fitoterapötik ajanlar önerebilir. Erkek infertiltesi tedavisinde tamamlayıcı tıp ajanlarının etkinliğinin güçlü olarak gösterilebilmesi için ileri düzey çalışmalara ihtiyaç vardır.

Anahtar Kelimeler: Tamamlayıcı tıp, erkek infertilitesi, fitoterapi

\section{GiRiș}

İnfertilite; en az bir yıl boyunca korunmasız ve düzenli cinsel ilişkiye rağmen gebelik oluşmaması demektir. Dünyada infertilite oranının $\% 15$ olduğu tahmin edilmektedir. ${ }^{[1]}$ İnfertil çiftlerde \%20-50 oranında erkek faktörü sorumludur ve erkek faktörüne bağlı infertilitede de $\% 30-40$ oranında sebep idiyopatikdir. ${ }^{[2]}$

Tamamlayıcı tıp modern tıbbın etkisini azaltmadan hastanın mevcut durumuna ek fayda sağlayacak uygulamalardir. NCCAM (Amerikan Ulusal Tamamlayıcı/Alternatif Tip Merkezi) tamamlayıcı tıbbı; klasik tıbbın tam olarak bir parçası olarak kabul edilmeyen, medikal ve sağlık bakım sistemleri, yöntemler ve ürünler gibi çeşitliliğe sahip bir grup uygulama olarak tanımlamaktadır. ${ }^{[3]}$ Günümüzde

Başakşehir Çam ve Sakura Şehir Hastanesi, İstanbul, Türkiye

Yazıșma Adresi/ Correspondence:

Uzm. Dr. Coşkun Kaçağan

Başakşehir Cam ve Sakura Sehir Hastanesi, 34480 İstanbul, Türkiye

Tel: $\quad+905064815312$

E-mail: ckacagan@gmail.com

Geliş/ Received: $\quad 15.05 .2021$

Kabul/ Accepted: $\quad$ 04.07.2021

\section{ABSTRACT}

The etiologies of approximately half of the male factor related infertility is still unclear. In addition to the modern medicine treatments, complementary medicine options are preferred frequently in the treatment of idiopathic infertility. With the increasing use of complementary medicine in modern medicine, these herbal agents are frequently preferred by patients. Anti-oxidant and phytotherapeutic agents can be recommended to subfertile men as a part of assisted reproductive methods although there is not enough evidence about live birth and pregnant rates. Further studies are needed to demonstrate the efficacy of complementary medicine agents in the treatment of male infertility.

Keywords: Complementary medicine, male infertility, phytotherapy

tamamlayıcı tıp uygulamaları hastalar tarafindan da sıklıkla tercih edilmektedir. Zini ve ark. 2004 yılında yaptıkları çalışmada Kanada da infertilite merkezine başvuran 500 erkek hastadan \%31'inin bir veya daha fazla tamamlayıcı tedavi aldığını, tamamlayıcı tedavi alanlarında \%63'ünün antioksidan vitamin ve mineral takviyeleri aldığı gösterilmiştir. ${ }^{[4]}$ İngiltere'de Boivin ve ark.'nın yaptıkları çalışmada infertilite sebebiyle sağlık kuruluşuna başvuran kadın hastaların \%63'ününün, erkek hastaların da \%25'inin tamamlayıcı tıp uygulamamalarından faydalandıkları gösterilmiştir. ${ }^{[5]} \mathrm{ABD}$ 'de infertil çiftlerin $\% 73$ 'ü tamamlayıcı tıp uygulamalarından faydalandıkları gösterilmiştir. ${ }^{[3]}$

$\mathrm{Bu}$ derlemenin amacı erkek infertilitesinde dünya çapında tamamlayıcı tedavi yöntemlerinin kanıt düzeyinin araştırılmasıdır.

\section{INFERTIL HASTALARDA TAMAMLAYICI TEDAVI YÖNTEMLERININ ETKI MEKANIZMALARI}

\section{Antioksidanların Etkisi}

Serbest oksijen radikalleri kararlı hale gelebilmek için diğer moleküllerle reaksiyona girebilecek aktif özellikli 
moleküllerdir. Bu serbest oksijen radikalleri metabolizmada oksijenin kullanıldığı reaksiyonlar sonucunda oluşurlar. ${ }^{[6]}$ Serbest radikaller hücre hasarındaki ve mikroorganizmaların öldürülmesindeki rollerine ek olarak, düşük konsantrasyonlarda hücrelerdeki sayısız sinyalizasyon yolağında, dolayısıyla birçok fizyolojik reaksiyonda da rol oynarlar. ${ }^{[7,8]}$ Serbest oksijen radikalleri hücrelerde normal olarak üretilir, sağlıklı hücrelerde hücre içi konsantrasyonları sıkı bir şekilde düzenlenir. Fizyolojik şartlarda serbest oksijen radikallerinin üretimi ve antioksidan sistemlerle yıkımı denge halindedir. Yaşlanma, ultraviyole ışınlar, ilaç kullanımı, immün sistem reaksiyonları, radyasyon maruziyeti, stres, sigara ve alkol kullanımı gibi faktörler bu dengeyi bozabilir. Oluşan fazla miktardaki serbest radikaller hücre içi bileşenler ile kolayca etkileşime girerek oksidatif strese neden olurlar. ${ }^{[7]}$ Semendeki serbest oksijen radikallerinin en önemli kaynakları immatür spermatozoa ve ejakulatta biriken lökositlerdir. Serbest radikaller sperm DNA ve mitokondrilerinde hasara neden olurlar. Bunun sonucunda da protein sentezi ve enerji üretiminde bozulmalar görülür; hücre zarında lipid peroksidasyonu oluşur. Böylece serbest radikaller bu olumsuz etkileri ile normal sperm yapısı ve hareketliliği bozulmakta, hücre zarındaki lipidlerin peroksidasyonuyla ortaya çıkan membran akışkanlığındaki bozukluk ile akrozomal reaksiyon defektleri ve sperm-ovum füzyon kusurları oluşmaktadır. Aynı zamanda DNA hasarı yoluyla sperm disfonksiyonu gelişmesine, hücre zarı bütünlüğünün bozulmasıyla hücre zarı geçirgenliğinde artış olması ve hücre ölümüne sebebiyet vermektedirler. ${ }^{[9]}$ Serbest radikalleri nötralize eden ve serbest radikal hasarını tamir etmeye yardımcı olan maddelere antioksidan maddeler denir. Antioksidan savunma sistemi; enzimatik ve non-enzimatik yollarla serbest oksijen radikallerini nötralize ederler. Enzimatik yolla etki gösterenler özellikle; süperoksit dismutaz, katalaz, glutatyon peroksidaz, glutatyon transferaz, mitokondriyal sitokrom oksidaz ve hidroperoksidaz, non-enzimatik yolla etkili olanlar ise; melatonin, seruloplazmin, transferrin, miyoglobin, hemoglobin, ferritin, bilirubin, glutatyon, sistein, metiyonin, ürat, laktoferrin, albümin, askorbat, flavonoidlerdir.

\section{Uzun Zincirli Yağ Asitlerinin Mitokondri İçine Transportu ve Beta Oksidasyon ile Enerji Sağlanımı}

L-karnitin, serbest yağ asidi metabolizmasında ve glukoz oksidasyonunda rol alan bir aminoasitdir ve yağ asitlerinin enerjiye dönüştürülmesinde görev alır. ${ }^{[10]}$ Uzun zincirli yağ asitlerinin mitokondri içindeki oksidasyonu sadece L-karnitin varlığında olmaktadır.
Serbest yağ asitleri, yağ açil-KoA sentetaz tarafından katalizlenen bir reaksiyon ile aktiflenir; yağ açil-KoA oluşur. Karnitin, yağ açil-KoA ile reaksiyona girer ve yağ açil karnitin oluşur. Reaksiyonu, karnitin palmitoil transferaz I katalizler. Oluşan yağ açil karnitin, karnitin açil translokaz tarafından mitokondri matriksine alınır. Matrikste yağ açil karnitinden karnitinin serbestleşmesi ile açil-KoA oluşur. Açil-KoA'nın mitokondri matriksinde beta oksidasyonu ile enerji elde edilir. Koenzim Q10, vücutta bütün hücre membranlarında ve sperm hücresinin iç mitokondri zarında yer alır. Koenzim Q10; mitokondri iç zarında ATP sentezini sağlayan elektron taşıma zincirinde kofaktör olarak rol oynar. Koenzim Q10 kompleks I ve II'deki elektronların kompleks III'e taşınması ve kompleks III stabilizasyonundan sorumludur. Koenzim Q10'un bu mekanizmalarla serbest radikal oluşumunu azaltarak antioksidan etki gösterdiği bazı çalışmalarda da gösterilmiştir. ${ }^{[11]}$

\section{Antiapoptotik Etki}

Apoptozun oluşmasında proteaz ailesi olarak bilinen Kaspaz'lar rol oynamaktadır. Hücreler iki yolak ile apoptoza gidebilmektedir. Birinci yolak, ekstrensek: ölüm reseptörü yolağı olarak da bilinir. İkinci yolak olan intrensek yolak ise ölüm reseptörü yolağından farklı olarak hem hücre dışı sinyallerle (büyüme faktörü veya hormon azlığı, ultraviyole 1şını, çeşitli sitokinler) hem de DNA hasarına neden olan hücre içi sinyallerle indüklenebilir. L-karnitin, Bcl-2 ekspresyonunu artırarak anti-apoptotik etki de göstermektedir. Çinko ise vücutta birçok önemli mekanizmada katalitik ve regülatör özellik gösteren bir iyondur; Testiküler steroidogeneziste, testis gelişiminde, spermatozoanın oksijen kullanımında, nükleer kromatin kümelenmesinde, akrozom reaksiyonunda, akrosin aktivitesinde, sperm kromatin stabilizasyonunda, testosterondan dihidrotestosteron oluşumunda önemli rol oynar. L-karnitin ve çinko ayrıca apoptotik programı başlatan ve yürüten çeşitli kaspazları ve FAS ile indüklenen apoptotik sinyallerin iletimini inhibe ederek antiapoptotik etki gösterirler. ${ }^{[12]}$

\section{Tek Karbon Halkası Olanların Etkisi}

Tek karbon metabolik siklusu antioksidatif mekanizmada hücresel metilasyon için oldukça önemlidir. Folik asit, B2, B3, B6, B12 gibi vitaminler bu siklusta rol alan önemli koenzimlerdendir. Homosisteinin metiyonine dönüşümü s1rasında bu moleküllerin ortama hazır metil donörü vermeleri ile hiperhomosisteineminin önüne geçilmekte ve DNA bütünlüğü korunmaktadır. ${ }^{[13]}$ Ayrıca homosistein üzerinden başlı başına güçlü bir antioksidan olan glutayon sentezlenir. Sperm vücutta en fazla metilasyon reaksiyonunun 
gerçekleştiği hücrelerden biridir ve bu metilasyon DNA bütünlüğü için, uygun gen ekspresyonu için ve fertilizasyon sonrası embriyo gelişimi için mutlaka gereklidir. ${ }^{[14]}$ Siklusta yer alan bu önemli koenzimlerin dışarıdan ilavesi ile tamamlayıcı tedaviler antioksidatif bir etki oluşturmaktadır. Tek karbon metabolik siklusu antioksidatif mekanizmada hücresel metilasyon için oldukça önemlidir.

\section{TAMAMLAYICI TEDAVI YÖNTEMLERINDEN BAZILARI VE KLINIIK ÇALIȘMALAR}

Koenzim Q10, sperm membranında lipid peroksidasyonunu inhibe ederek ve superoksit anyon oluşumunu azaltması vasıtasıyla antioksidan etki gösterir. ${ }^{[11]} 2014$ yılında yapılan randomize plasebo-kontrollü bir çalışmada 60 idiyopatik oligoastenoteratozospermik hastanın Koenzim Q10 tedavisi alan kolunda semendeki süperoksit dismutaz ve katalaz düzeylerinin Koenzim Q10 ile pozitif korele şekilde arttığı görülmüştür. Ayrıca Koenzim Q10 konsantrasyonu ile normal sperm morfolojisi ve sperm motilite oranlarında da anlamlı korelasyonlar tespit edilmiştir. ${ }^{[15]}$ Lafuente ve ark., yaptıkları sistematik derleme ve meta-analizde 3 plasebo-kontrollü çalışma incelenmiş; koenzim Q10 tedavisinin sperm motilitesi ve semen konsantrasyonlarında anlamlı artışa neden olduğu ancak canlı doğum ve gebelik gelişimine bir etkisinin olmadığı belirlenmiştir. ${ }^{[16]}$

E vitamini, serbest radikaller tarafindan lipid peroksidasyonuyla oluşturulan hücre membran hasarını önlemede ve diğer antioksidanların aktivitesini düzenlemede önemli rol oynar. ${ }^{[17]}$ Ayrıca 2005 yılında yapilan bir çalışmada E vitamininin tek başına ya da $\mathrm{C}$ vitamini kombinasyonuyla DNA fragmantasyonunu düzelttiği ve spermatozoanın zona pellicuda'ya bağlanmasını kolaylaştırdığı gösterilmiştir. ${ }^{[18]}$ Yapılan randomize plasebo kontrollü bir çalışmada normal kadın faktörlü 30 infertil erkek hastanın semenlerinde yüksek ROS görülmüştür. İki gruba ayrılan hastalara üç ay boyunca $\mathrm{E}$ vitamini $(600 \mathrm{mg} /$ gün$)$ ve plasebo tedavi verilmiştir. IVF (in-vitro fertilizasyon) yapılan hastalarda E vitamini verilenlerde spermin zona pellucida'ya bağlanma kapasitesinde anlamlı artış görülmüştür. ${ }^{[19]}$ Geva ve ark.'nın çalışmasında da önceden yapılmış IVF sikluslarında düşük fertilizasyon oranı ve yüksek malondialdehit düzeyi olan normospermik 15 erkeğe üç ay süreyle $\mathrm{E}$ vitamini (200 mg/gün) tedavisi verilmiştir. Hastaların sperm morfolojisinde herhangi bir iyileşme görülmemiştir ancak siklus başına düşen fertilizasyon oranının \%19,3'den \%29,1'e yükseldiği ve malondialdehit düzeylerinde ise anlamlı azalmalar olduğu görülmüştür. Düşük fertilizasyon başarısı olan normospermik erkeklerde E vitamininin lipid peroksidasyonunu azaltarak fayda sağladığı belirtilmiştir. ${ }^{[20]}$
Folik asit, DNA sentezi, RNA transferi gibi görevlerinin yanında esansiyel aminoasitler için de oldukça önemlidir. En önemli antioksidanlardan birisi olan glutatyon ve metiyonin oluşumunda diğer B vitaminleri ile etkileşime girerek önemli rol oynar. ${ }^{[21]}$ Ayrıca lipid peroksidasyonunu inhibe ederek DNA ve hücre membranını serbest radikallere karşı korur. ${ }^{[22]}$ Seminal plazmadaki folik asit konsantrasyonunun düşük seviyelerde olmasının sperm DNA hasarı ile korele olduğu, hasar arttıkça da sperm motilite ve morfolojide bozulmaların olduğu gösterilmiştir ve seminal folik asit düzeyi düşüklüğü ile düşük sperm konsantrasyonu arasında bir korelasyon olduğu gösterilmiştir. ${ }^{[23]}$ Wong ve ark., subfertil hastalarda folik asidin etkinliğini değerlendirmek amacıyla yaptıkları randomize plasebo kontrollü çalışmada sperm konsantrasyonlarında artış sağlandığı ancak motilite ve morfoloji parametrelerinde etkili olmadığ gösterilmiştir. ${ }^{[24]}$

Çinko; önemli enzimatik reaksiyonlarda katalitik ve regülatör özellikler gösteren bir antioksidan iyondur. Birçok makromolekülün fonksiyonunda ve 3000 'in üzerinde proteinin yapısında rol oynamaktadır. DNA yapımı ve protein sentezinde rol alan çok sayıda enzimin esansiyel kofaktörüdür. ${ }^{[25]}$ Çinkonun testiküler steroidogeneziste, testislerin gelişiminde, spermatozoanın oksijen kullanımı sırasında, nükleer kromatin kümelenmesinde, akrozom reaksiyonunda, akrosin aktivitesinde, sperm kromatin stabilizasyonunda ve testosterondan dihidrotestosteron oluşumunda önemli görevleri vardır. ${ }^{[22]}$ Yapılmış bir çalışmada; çinko eksikliği durumunda oligospermi, hipogonadizm ve immün sistem fonksiyonlarında bozulmalar olduğu bildirilmiştir. ${ }^{[26]}$ Yüz adet astenozoospermisi olan hastanın değerlendirildiği plasebo kontrollü çalışmada, çinko tedavisi sonunda sperm sayısı ve hareketliliği ile fertilizasyon kapasitesinde kontrol grubuna göre anlamlı artış, antisperm antikor düzeylerinde ise anlamlı azalmanın olduğu gösterilmiştir. ${ }^{[27]}$ Fertil/infertil hastalardaki seminal plazma çinko düzeylerinin karşılaştırıldığı randomize çift-kör plasebo kontrollü bir çalışmada infertil hastalarda seminal plazma çinko düzeylerinin daha düşük olduğu, seminal plazma çinko düzeyi ile sperm sayısı, motilitesi ve canlılığı arasında anlamlı pozitif korelasyon olduğu bildirilmiştir. ${ }^{[24]}$

L-karnitin enerji üretiminde önemli rol oynayan, metiyonin ve lizin aminoasitlerinden oluşan, suda çözünebilen polar yapıya sahip bir moleküldür. L-karnitin uzun zincirli yağ asitlerinin mitokondri içine transportunu ve beta oksidasyonu sağlayarak metabolizmaya enerji sağlanmasına yardımcı olur. Oksidatif stres sonucu oluşan hasarın tamirini sağlayarak antiapoptotoik etki gösterirler. Ayrıca araşidonik asidin membran fosfolipidleri ile etkileşimini inhibe etme gibi önemli fonksiyonları vardır. Erkek 
infertilitesindeki etkisini antioksidatif ve antiapoptotik özellikleri ile sağlamaktadır. L-karnitin'in vücutta en fazla bulunduğu yer epididimin kaput kısmıdır. Epididim lümeninde karnitin ile etkileşen spermatozoa olgunlaşarak ileri hareketlilik kapasitesi kazanır. Ayrıca sertoli hücrelerine glukoz alımını uyararak testiküler sperm maturasyonunda görev almaktadır. Yedi adet randomize kontrollü çalışmanın idyopatik oligoastenozospermik 751 hastasının değerlendirildiği bir meta-analizde, L-karnitin tedavisi sonrası spontan gebelik oranlarında anlamlı artışların olduğu görülmüştür. Ayrıca total sperm motilitesinde anlamlı artışların ve anormal morfolojili sperm yüzdesinde anlamlı azalmaların olduğu gösterilmiştir. ${ }^{[28]} 2015$ yılında idyopatik oligoastenozoospermik hastalar üzerinde yapılan çalışmada karnitin tedavisinden sonra Malondialdehid (MDA) düzeylerinin azaldığı, semen volümünün arttı̆̆ı, sperm motilitesi ve morfolojide düzelmeler olduğu görülmüsstür. ${ }^{[29]}$

Omega 3 yağ asitleri vücutta üretilmeyen yağ asitleridir. $\mathrm{Bu}$ yüzden besinlerle alınamadığ 1 takdirde gida takviyeleri ile karşılanması gerekmektedir. Lipid yapıdaki çift katlı hücre zarının akışkanlığını sağlar. Böylece spermatozoanın başarılı fertilizasyonunu ve sperm-oosit füzyonunu kolaylaştırır. Süperoksit üretimini azaltması, glutatyon peroksidazı artırması ve sperm DNA hasarını azaltmasıyla da antioksidan özellik gösterir. 2018'de yayımlanan sistematik derleme ve meta-analizde; infertile erkek hastalarda Dokosaheksaenoik asit (DHA) ve Eikosapentaenoik asit (EPA)'nin sperm konsentrasyonu, sperm motilitesi, sperm DHA ve seminal plasma DHA üzerine olan etkileri derlenmiştir. (Temel Omega 3 yağ asitleri; Alfa-linolenik asit, Eikosapentaenoik asit, Dokosaheksaenoik asit'dır). Bu derlemede üç randomize kontrollü çalışma incelenmiştir. İnfertil erkek hastalara tek başına DHA ve EPA veya kombinasyon halinde verilmiştir. Seminal DHA konsantrasyonunda, sperm konsantrasyonu ve motilitesinde anlamlı artış olduğu görülmüştür. ${ }^{[30]}$ Yapılan bir vaka-kontrol çalışmasında varikoseli olan yada olmayan infertil hastalar ile fertil erkeklerin spermatozoasındaki Omega 3 konsantrasyonları karşılaştırılmıştır. Varikoselli infertil grupta Omega 3 düzeylerinin daha düşük olduğu ve bu düşüklüğün varikosel derecesi ve sperm DNA hasarı ile korele olduğu gösterilmiştir. ${ }^{[31]}$ Oligoastenoteratozoospermik infertil hastaların değerlendirildiği randomize plasebo kontrollü bir çalışmada da Omega 3 yağ asidi tedavisi verilen grupta sperm sayısı, motilite ve morfolojilerinde plaseboya göre anlamlı iyileşmeler gözlenmiştir. ${ }^{[32]}$

Selenyum, hücre zarını oksidatif hasardan koruyan ametal bir elementtir. Selenyum hücre zarlarını oksidatif hasarlardan koruyan glutatyon peroksidaz gibi önemli enzimlerin katalitik merkezinin aktif bölgelerinde selenosistein formunda yer almaktadır. Selenyum normal testiküler gelişim, spermatogenezis ve sperm kapasitasyon sürecinde gerekli olan bir elementtir. ${ }^{[33]}$ Dört yüz altmış sekiz infertil hasta üzerinde antioksidan olarak selenyumun kullanılmış ve selenyum tedavisinin hem sperm konsantrasyonu hem de motilite ve morfolojide anlamlı iyileşmeler sağladığ gösterilmiştir. ${ }^{[34]}$ Yayımlanan bir derlemede de, selenyum eksikliğinin semen kalitesinde ve sperm motilitesindeki bozulmaya neden olduğu ve erkek infertilitesiyle ilişkili olabileceği belirtilmiştir. ${ }^{[35]}$

2019 yılında yapılan sistematik derlemede 59 adet randomize kontrolleri çalışma ve iki adet non-randomize kontrollü çalışma değerlendirilmiştir. Bu çalışmalarda Pentoksifilin, CoQ10, L karnitin kullanımı ile canlı doğum oranlarında; Pentoksifilin, CoQ10, L karnitin ile sperm konsantrasyonunda; Pentoksifilin, CoQ10, L karnitin, tamoksifen ve kallikrein kullanımında sperm motilitesinde; Pentoksifilin, CoQ10, L karnitin, L karnitin ve asetilkarnitin kombinasyonu ve kalikrein kullanımında normal sperm morfolojisinde artışlar olduğu gösterilmiştir. ${ }^{[36]}$

Oral vitamin ve mineral takviyelerinin erkek infertilitesi üzerine etkilerini inceleyen sistematik derlemede; 18 adet randomize, çift kür, plasebo-kontrollü çalışma, dört adet meta-analiz ve üç adet derleme incelenmiştir. Selenyum ve $\mathrm{N}$-asetil-sistein kombinasyonu, çinko ve folik asit kombinasyonu, Omega 3, L-carnitine ve LAC kombinasyonu, koenzim Q10 kullanımının semen parametrelerinde plaseboya kıyasla anlamlı artışa sebep olduğu gösterilmiştir. Bunların dışındaki takviyelerin kanıt düzeylerinin yetersiz oldukları görülmüştür. ${ }^{[37]}$

C vitamini, güçlü bir antioksidandır. İnterselüler matriksin komponentlerinden birisidir. Kollajen ile proteoglikan sentezinde görev alır. Seminal plazmadaki $\mathrm{C}$ vitamini konsantrasyonu seruma kıyasla yaklaşık 10 kat daha fazladır. Ayrıca seminal plazmadaki antioksidan kapasitenin \%65'ine yak1nını oluşturur. ${ }^{[38]} 2006$ yılında yapılan bir çalışmada seminal C vitamini düzeyi ile sperm DNA fragmantasyon indeksi skoru karşılaştırılmıştır. Seminal C vitamini düzeyi düşük hastalarda DNA fragmantasyon indeksi skoru yüksek saptanmıştır. ${ }^{[39]}$ Seminal vitamin C düzeyinin semen parametreleri üzerine etkisinin araştırıldığı hem fertil hem de infertil hasta gruplarının dahil edildiği bir çalışmada da, seminal vitamin C düzeylerinin infertil hastalarda anlamlı oranda düşük olduğu saptanmıştır. Ayrıca sperm morfolojisi ile seminal C vitamini düzeyi arasında da anlamlı korelasyon olduğu belirtilmiştir. ${ }^{[40]}$ Yapılan randomize, plasebo kontrollü bir çalışmada klinik varikoseli olan 115 infertil hastaya varikoselektomi yapıldıktan sonra üç ay boyunca bir gruba vitamin $\mathrm{C}$, diğer gruba plasebo verilerek semen 
analizleri karşılaştırılmıştır. Vitamin C alan grupta motilite ve morfolojide anlamlı düzelme izlenirken sperm konsantrasyonları her iki grupta benzer bulunmuştur. ${ }^{[41]}$

Cochrane Veritabanında; antioksidanların aralarındaki karşılaştırmalarında, canlı doğum ve klinik gebelik oranları üzerine rapor yoktur. Sperm parametreleri için; yüksek heterojenite nedeniyle antioksidanların birbirlerine üstünlüğü konusunda herhangi bir değerlendirme yapılamamıştır. Antioksidanların farklı dozlarda farklı etkiler yapıp yapmadıkları hususunda yeterli kanıt yoktur (Tablo 1). ${ }^{[42]}$

\section{FITOTERAPI}

Hastalıklardan korunmak ve tedaviyi desteklemek amacı ile tıbbi etkisi bilimsel olarak kanıtlanmış bitkiler, onların etkin maddelerini taşıyan kısımları ve/veya bir işlem yoluyla elde edilmiş doğal ürünleri ile bunlardan hareketle hazırlanarak standardize edilmiş farmasötik formlar (tablet, kapsül, vb.) kullanılarak yapılan uygulamalardır. WHO verilerine göre dünya nüfusunun \%70-80’inin, kendi geleneksel kültüründeki bitkisel ilaçları tercih ettiğini göstermiştir. Bitkisel ajanların erkek infertilitesindeki başarısının mekanizması tam olarak aydınlatılamamıştır. Ancak çalışmalardan elde edilen verilere göre en muhtemel mekanizmalar antioksidatif, antiinflamatuar, antiödematöz ve hormonal etkilerdir.

Fitoterapiye ilgi giderek artmaktadır ve yan etkilerinin olmadığı kabul edilmektedir. Maliyetinin düşük olması, kolay elde edilebilir olması, artan ilgi nedeniyle yapılan bilimsel araştırmaların her geçen gün artmasına neden olmaktadır. Araştırmalar incelendiğinde fitoterapi ile semen parametreleri arasında anlamlı etkileşimler olduğu görülmektedir. ${ }^{[43]} \mathrm{Bu}$ sebeplerden Avrupa, $\mathrm{ABD}$ ve gelişmekte olan ülkelerde kültürel uygunluk olduğu sürece fitoterapinin kullanımı giderek yaygınlaşmaktadır. Türkiye'de yapılmış bir çalışmada, 151 infertil çift incelenmiştir. Kadınların \%35,8'i, erkeklerin \%25,8'i herhangi bir dönemde fitoterapiden faydalandıkları görülmüştür. ${ }^{[44]}$

\section{Fitoterapötik Ajanlar}

Tribulus terrestris (demir dikeni); diüretik, afrodizyak, antienflamatuar, antidiabetik, analjezik, antibakteriel etkinlik göstermektedir. İçerdiği protodiosin molekülü sayesinde testosteron düzeyini artırarak libido ve seksüel aktivite üzerine olumlu etkileri mevcuttur. Bir çalışmada semen parametreleri bozuk 65 infertil erkeğe 12 hafta boyunca 250 mg Tribulus Terrestis ekstresi verilmiştir. Bu dönem içinde hastaların vücut yağ oranları, kas kitlesi miktarları, steroid hormon seviyelerindeki dalgalanmalar ve semen parametreleri değerlendirilmiştir. Çalışmanın sonunda; bu hastalarda vücut yağ oranının düştüğ̈̈, vücut kas kitlesinde artış olduğu ve Dihidrotestesteron seviyelerinde, sperm konsantrasyonunda ve sperm motilitesinde artış olduğu görülmüştür. ${ }^{[45]}$

Macuna (Kadife fasulye) içerisinde fazla miktarda L-Dopa bulunmaktadır. L-Dopa kan beyin bariyerini geçtikden sonra aynı zamanda GnRH salgısınıda uyarmaktadır. ${ }^{[46,47]}$ Artan GnRH FSH ve LH salınımını stimüle etmektedir. Sonuç olarak spermatogenesis ve testesteron üretimi artmaktadır. ${ }^{[48,49]}$ Ayrıca macuna dan gelen L-Dopa, prolaktin

\section{Tablo 1.}

\begin{tabular}{lcccc}
\hline Sperm sayısı & Sperm motilitesi & DNA fragmantasyon & Klinik Gebelik & Canlı doğum \\
\hline Folik asit & Selenyum & E vitamini & E vitamini & E vitamini \\
Selenyum & L-karnitin & C vitamini & Çinko & Çinko \\
L-karnitin & Koenzim Q10 & Omega 3 & & \\
Koenzim Q10 & & & \\
\hline
\end{tabular}

Tablo 2.

\begin{tabular}{lcc}
\hline Etkili olan yaşam şekli değişiklikleri & Etkili olan supplement'ler & Yeterli kanıt olmayanlar \\
\hline Kilo verme & Koenzim Q10 & C vitamini \\
Sigara bırakma & L-karnitin & E vitamini \\
Alkol alımını ılımlı hale getirme & Glutatyon & Safran \\
& Omega 3 & Akupunktur \\
& Selenyum & Skrotal soğutma \\
\end{tabular}


salınımını da inhibe ederek testesteron seviyesinin artışına neden olmaktadır. ${ }^{[4]}$ Macuna ve ashwagandha (Hint Ginsengi); seminal A, C, E vitaminlerini ve früktoz seviyelerini artırmaktadır. Macuna, seminal lipid miktarınıda artırmaktadır. ${ }^{[00]}$ Ashwagandha da antioksidan enzimlerin seviyesini artırmaktadır. Böylece A, C, ve E vitaminlerinin artmasıyla sperm lipid peroksidasyonu azalıyor; früktoz ve lipid seviyesinin artması ile spermatozoa lar için substrat artıyor. İki bitkinin birlikte alınmasıyla semen miktarın$\mathrm{da}$, sperm sayısında ve motilitesinde artış gözleniyor. ${ }^{[50]}$ Yapılan bir çalışmada ise mucuna, ashwagandha 12 hafta boyunca oligospermik erkeklere $5000 \mathrm{mg} / \mathrm{dl}$ olacak şekilde verildikten sonra total testesteron ve semen parametrelerinde anlamlı artışlar olduğu görülmüştür. ${ }^{[51]}$

Cucurbita Pepo (Kabak Çekirdeği) yă̆ asitleri, fitosteroller, proteinler, karotenoidler, E vitamini, çinko ve selenyum açısından oldukça zengindir. Sperm hareketi için gerekli önemli moleküllerin prekürsörü olan arjinin aminoasidini yüksek oranda ihtiva ettiğinden infertiliteye pozitif bir katkısının olduğu düşünülmektedir. Deneysel bir çalışmada kabak çekirdeği ekstresi verilen ratlarda antioksidatif etki ile siklofosfamidin reprodüktif sistem üzerindeki istenmeyen etkilerin antagonize edildiği ve sperm parametrelerinde iyileşme sağlandığı gösterilmiştir. ${ }^{[22]}$

Zingiber Officiale (Zencefil); antioksidan ve antienflamatuar özellikleri vardır. İnfertil 100 erkeğin değerlendirildiği randomize kontrollü çift-kör çalışmada zencefil tedavisi alan grupta sperm DNA fragmantasyonunun anlamlı şekilde azaldığı ancak semen parametrelerinde önemli bir değişiklik olmadığı bildirilmiştir. ${ }^{[30]}$ Birçok deneysel çalışmada zencefilin semen parametrelerini iyileştirdiği gösterilmiştir. ${ }^{[53]}$

Cinnamomum Zaylanicum (tarçın) içerdiği sinnamaldehit sayesinde güçlü bir antioksidan özellik gösterir. Ülkemizde yapılan deneysel bir çalışmaya göre; 10 hafta boyunca günlük $100 \mathrm{mg} / \mathrm{kg}$ tarçın kabuğu yağı verilen ratlarda testiküler malondialdehid düzeyinin azaldığı, katalaz, glutatyon peroksidaz ve glutatyon düzeylerinin anlamlı şekilde arttığ bildirilmiştir. Ayrıca sperm parametrelerinin kontrol grubuna göre anlamlı şekilde iyileştiği gösterilmiştir. ${ }^{[54]}$

Nigella sativa (Çörek otu); içerdiği timokinon ve karvakrol molekülleri ile semendeki reaktif oksijen radikallerini nötralize eder. İçerdiği zengin Omega 3 yağ asidi sayesinde testosteron sentezindeki önemli enzimlerden birisi olan beta hidroksisteroid dehidrogenazın aktivitesini artırmaktadır. Oligoastenoteratozoospermik hastaların değerlendirildiği randomize çift-kör plasebo-kontrollü çalışmada; normal sperm morfolojisi \%30'un altında, sperm sayısı 20 milyonun altında veya tip A ve tip B motiliteleri sırasıly $\% 25$ ve \%50'nin altında olan erkekler çalı̧̧maya dâhil edilmiştir. İki ay boyunca çörek otu tohumu yağı 2,5 ml günde olacak şekilde verilmiştir. Çörek otu tohumu yağı verilen grubun sperm parametrelerinde kontrol grubuna göre anlamlı şekilde düzelmeler görülmüştür. ${ }^{[5]}$

Sesamum İndicum (Susam) içerdiği zengin doymamış yağ asidi ve tokoferoller sayesinde antiöstrojenik ve antioksidan özellik gösterirler. İnfertil 25 hastanın değerlendirildiği klinik çalışmada, üç ay susam tedavisi sonrasında hastaların sperm sayısı ve motilitesinde anlamlı düzelmelerin görüldüğ̈̈ bildirilmiştir. ${ }^{[56]}$

2014'de yapılmış bir çalışmada en az iki defa yardımcı üreme yöntemlerinden (assisted reproductive technology - ART) faydalanan çiftlerdeki erkek partnerler üzerinde tek karbon bağı içeren besin takviyeleri değerlendirilmiştir. Çalışmaya dâhil edilenler infertiliteye sebep olabilecek organik bir durumu olmayan, DNA fragmantasyon indeksi (DFI) ve nuclear decondensation indeksi (SDI) \%20'i geçen erkeklerdir. Çalışmadaki erkeklere B vitamin kompleksleri, çinko, proprietary opuntia (dikenli incir bitkisi) ekstresi ile düşük miktarda $\mathrm{N}$-acetyl-cysteine ve $\mathrm{E}$ vitamin kombinasyonları (Condensyl ${ }^{\mathrm{TM}}$ ) verilmiştir. SDI'da \%64,3, DFI'da \%71,4 düzelme olduğu görülmüş. Tek karbon halkalı besin takviyeleri ART olmasına rağmen gebelik oluşmayan vakalarda hem SDI, DFI hemde gebelik insidansin da artışa neden oldukları görülmüştür. ${ }^{[57]}$ Tek karbon halkalı besin takviyeleri; Betalain $(0,001 \mathrm{mg}), \mathrm{B} 2(1,4 \mathrm{mg}), \mathrm{B} 3$ $(16 \mathrm{mg}), \mathrm{B} 6(1,4 \mathrm{mg}), \mathrm{B} 9(400 \mu \mathrm{g}), \mathrm{B} 12(2,5 \mu \mathrm{g})$, Çinko $(12,5 \mathrm{mg}), \mathrm{N}$-acetylcysteine $(250 \mathrm{mg})$, vitamin $\mathrm{E}(12 \mathrm{mg})$, Dikenli incir bitkisi ekstresi $(100 \mathrm{mg})$ olarak özetlenebilir.

2018 yılında 270 çalışmanın sistematik derlemesinde 12 farklı tamamlayıcı tedavi yöntemi değerlendirilmiştir. Akupunkturun bu tamamlayıcı tedaviler içerisinde erkek ve kadın fertilitesinde artışa neden olduğu görülmüştür. ${ }^{[58]}$ Oligoasthenozoospermisi olan erkekler üzerinde akupunkturun etkinliğini araştıran bir sistematik derlemede de; 12 randomize kontrollü çalışmada toplamda 1088 hasta incelenmiştir. Akupunktur veya akupunktur ile kombine edilmiş tedavi yaklaşımlarının semen kalitesini artırdığı gösterilmiştir. ${ }^{[59]}$ Metodolojik kalite düşüklüğü nedeniyle infertil erkek hastalarda akupunkturu önermek için kanıt düzeyi yetersiz, kesin sonuç elde edilmesi için daha kapsamlı çalışmalar gerektiği vurgulamışdır.

\section{SONUÇ}

İdiyopatik erkek infertilitesinin tedavisinde tamamlayıc1 tıptan faydalanılabilir. Kanıt düzeyinin yeterli olduğu grup: vitamin ve mineraller, Koenzim Q10, L-karnitin, selenyum, çinko-folik asit kombinasyonu, Omega 3 dür. 
Bunun yanında fitoterapötik ajanlar konusunda yeterli kanıt düzeyi yoktur (çalışmalar heterojendir). Tamamlayıcı tedaviler için yapılan çalışmalarda örnekleme sayısı yetersiz ve metodolojik olarak düşük kalitelidir.

\section{Hakem Değerlendirmesi}

Dış bağımsız.

\section{Çıkar Çatışması}

Yazarlar çıkar ilişkisi olmadığını beyan etmişlerdir.

\section{Finansal Destek}

Herhangi bir mali destek alınmamıştır.

\section{Peer-review}

Externally peer-reviewed.

\section{Conflict of Interest}

No conflict of interest was declared by the authors.

Financial Disclosure

No financial support has been received.

\section{KAYNAKLAR}

1. Agarwal A, Mulgund A, Hamada A, Chyatte MR. A unique view on male infertility around the globe. Reprod Biol Endocrinol 2015;13:37. [CrossRef]

2. Turek P. Male reproductive physiology. In: Wein AJ, Partin AW, Peters CA, editors. Campbell-Walsh Urology, 10th ed. USA: Elsevier Saunders; 2012.

3. Millet JD. Progress in complementary and alternative medicine research: Yale Research Symposium on Complementary and Integrative Medicine. Yale J Biol Med 2010;83:127-9. https:// www.ncbi.nlm.nih.gov/pmc/articles/PMC2946125/

4. Zini A, Fischer MA, Nam RK, Jarvi K. Use of alternative and hormonal therapies in male infertility. Urology 2004;63:141-3. [CrossRef]

5. Boivin J, Bunting L, Collins JA, Nygren KG. International estimates of infertility prevalence and treatment-seeking: potential need and demand for infertility medical care. Human Reprod 2007;22:1506-12. [CrossRef]

6. Can O, Canat L. Erkek İnfertilitesi ve Erektil Disfonksiyon Tedavisinde Tamamlayıcı Tıp: Moleküler Düzeyde Etki Mekanizmaları ve Klinik Sonuçlar. Androl Bul 2020;22:43-51. [CrossRef]

7. Cabello-Verrugio C, Simon F, Trollet C, Santibañez JF. Oxidative stress in disease and aging: Mechanisms and therapies 2016. Oxidative Med Cell Longevity 2016;2017:4310469. [CrossRef]

8. Ratnam DV, Ankola D, Bhardwaj V, Sahana DK, Kumar MR. Role of antioxidants in prophylaxis and therapy: A pharmaceutical perspective. J Controlled Release 2006;113:189-207. [CrossRef]

9. Ko EY, Sabanegh Jr ES, Agarwal A. Male infertility testing: reactive oxygen species and antioxidant capacity. Fertil Steril 2014;102:1518-27. [CrossRef]

10. Caraccio TR, Mofenson HC. Carnitine. J Toxicol Clin Toxicol 2003;41:897. [CrossRef]

11. Nohl H, Gille L, Staniek K. The biochemical, pathophysiological, and medical aspects of ubiquinone function. Ann N Y Acad Sci 1998;854:394-409. [CrossRef]

12. Balercia G, Regoli F, Armeni T, Koverech A, Mantero F, Boscaro M. Placebo-controlled double-blind randomized trial on the use of L-carnitine, L-acetylcarnitine, or combined L-carnitine and L-acetylcarnitine in men with idiopathic asthenozoospermia. Fertil Steril 2005;84:662-71. [CrossRef]
13. Singh K, Jaiswal D. One-carbon metabolism, spermatogenesis, and male infertility. Reprod Sci 2013;20:622-30. [CrossRef]

14. Kumar M, Kumar K, Jain S, Hassan T, Dada R. Novel insights into the genetic and epigenetic paternal contribution to the human embryo. Clinics 2013;68:5-14. [CrossRef]

15. Nadjarzadeh A, Shidfar F, Amirjannati N, Vafa MR, Motevalian SA, Gohari MR, et al. Effect of Coenzyme Q10 supplementation on antioxidant enzymes activity and oxidative stress of seminal plasma: a double-blind randomised clinical trial. Andrologia 2014;46:177-83. [CrossRef]

16. Lafuente R, González-Comadrán M, Solà I, López G, Brassesco M, Carreras R, Checa MA. Coenzyme Q10 and male infertility: a meta-analysis. J Assist Reprod Genet 2013;30:1147-56. [CrossRef]

17. Brigelius-Flohé R, Traber MG. Vitamin E. function and metabolism. FASEB J 1999;13:1145-55. [CrossRef]

18. Greco E, Iacobelli M, Rienzi L, Ubaldi F, Ferrero S, Tesarik J. Reduction of the incidence of sperm DNA fragmentation by oral antioxidant treatment. J Androl 2005;26:349-53. [CrossRef]

19. Kessopoulou E, Powers HJ, Sharma KK, Pearson MJ, Russell JM, Cooke ID, Barratt CL. A double-blind randomized placebo cross-over controlled trial using the antioxidant vitamin $\mathrm{E}$ to treat reactive oxygen species associated male infertility. Fertil Steril 1995;64:825-31. [CrossRef]

20. Geva E, Bartoov B, Zabludovsky N, Lessing JB, Lerner-Geva L, Amit A. The effect of antioxidant treatment on human spermatozoa and fertilization rate in an in vitro fertilization program. Fertil Steril 1996;66:430-4. [CrossRef]

21. Goszcz K, Deakin SJ, Duthie GG, Stewart D, Leslie SJ, Megson IL. Antioxidants in cardiovascular therapy: panacea or false hope? Front Cardiovasc Med 2015;2:29. [CrossRef]

22. Ebisch I, Thomas C, Peters W, Braat D, Steegers-Theunissen R. The importance of folate, zinc and antioxidants in the pathogenesis and prevention of subfertility. Human Reprod Update 2007;13:16374. [CrossRef]

23. Boxmeer JC, Smit M, Utomo E, Romijn JC, Eijkemans MJ, Lindemans $\mathrm{J}$, et al. Low folate in seminal plasma is associated with increased sperm DNA damage. Fertil Steril 2009;92:548-56. [CrossRef]

24. Wong WY, Merkus HM, Thomas CM, Menkveld R, Zielhuis GA, Steegers-Theunissen RP. Effects of folic acid and zinc sulfate on male factor subfertility: a double-blind, randomized, placebocontrolled trial. Fertil Steril 2002;77:491-8. [CrossRef]

25. Maret W. Zinc and human disease. In: Sigel A., Sigel H., Sigel R, editors. Interrelations Between Essential Metal Ions and Human Diseases. Metal Ions in Life Sciences, vol 13. Dordrecht: Springer; 2013. p.389-414. [CrossRef]

26. Prasad AS. Zinc in human health: effect of zinc on immune cells. Mol Med 2008;14:353-7. [CrossRef]

27. Omu AE, Dashti H, Al-Othman S. Treatment of asthenozoospermia with zinc sulphate: andrological, immunological and obstetric outcome. Eur J Obstet Gynecol Reprod Biol 1998;79:179-84. [CrossRef]

28. Shang X, Wang L, Mo D, Cai H, Zheng D, Zhou Y. Effect and safety of L-carnitine in the treatment of idiopathic oligoasthenozoospermia: a systemic review. Zhonghua Nan Ke Xue 2015;21:65-73. https://pubmed.ncbi.nlm.nih. gov/25707144/

29. Nada E, El Taieb M, Ibrahim H, Al Saied AR. Efficacy of tamoxifen and 1-carnitine on sperm ultrastructure and seminal oxidative stress in patients with idiopathic oligoasthenoteratozoospermia. Andrologia 2015;47:801-10. [CrossRef] 
30. Hosseini B, Nourmohamadi M, Hajipour S, Taghizadeh M, Asemi Z, Keshavarz SA, Jafarnejad S. The effect of omega-3 fatty acids, EPA, and/or DHA on male infertility: a systematic review and meta-analysis. J Dietary Suppl 2019;16:245-56. [CrossRef]

31. Tang L-X, Yuan D-J, Wang Q-L, Jiang F, Guo J, Tang Y-G, et al. Association of decreased spermatozoa omega-3 fatty acid levels and increased oxidative DNA damage with varicocele in infertile men: a case control study. Reprod Fertil Dev 2016;28:648-54. [CrossRef]

32. Safarinejad MR. Efficacy of coenzyme Q10 on semen parameters, sperm function and reproductive hormones in infertile men. J Urol 2009;182:237-48. [CrossRef]

33. Ursini F, Heim S, Kiess M, Maiorino M, Roveri A, Wissing J, Flohé L. Dual function of the selenoprotein PHGPx during sperm maturation. Science 1999;285:1393-6. [CrossRef]

34. Safarinejad MR, Safarinejad S. Efficacy of selenium and/or $\mathrm{N}$-acetyl-cysteine for improving semen parameters in infertile men: a double-blind, placebo controlled, randomized study. J Urol 2009;181:741-51. [CrossRef]

35. Pieczyńska J, Grajeta $H$. The role of selenium in human conception and pregnancy. J Trace Elem Med Biol 2015;29:31-8. [CrossRef]

36. Omar MI, Pal RP, Kelly BD, Bruins HM, Yuan Y, Diemer T, et al. Benefits of empiric nutritional and medical therapy for semen parameters and pregnancy and live birth rates in couples with idiopathic infertility: a systematic review and meta-analysis. Eur Urol 2019;75:615-25. [CrossRef]

37. Buhling K, Schumacher A, Zu Eulenburg C, Laakmann E. Influence of oral vitamin and mineral supplementation on male infertility: a meta-analysis and systematic review. Reprod Biomed Online 2019;39:269-79. [CrossRef]

38. Lewis SE, Sterling ESL, Young IS, Thompson W. Comparison of individual antioxidants of sperm and seminal plasma in fertile and infertile men. Fertil Steril 1997;67:142-7. [CrossRef]

39. Song GJ, Norkus EP, Lewis V. Relationship between seminal ascorbic acid and sperm DNA integrity in infertile men. Int J Androl 2006;29:569-75. [CrossRef]

40. Colagar AH, Marzony ET. Ascorbic Acid in human seminal plasma: determination and its relationship to sperm quality. J Clin Biochem Nutr 2009;45:144-9. [CrossRef]

41. Cyrus A, Kabir A, Goodarzi D, Moghimi M. The effect of adjuvant vitamin $\mathrm{C}$ after varicocele surgery on sperm quality and quantity in infertile men: a double blind placebo controlled clinical trial. Int Braz J Urol 2015;41:230-8. [CrossRef]

42. Smits RM, Mackenzie-Proctor R, Yazdani A, Stankiewicz MT, Jordan V, Showell MG. Antioxidants for male subfertility. Cochrane Database Syst Rev 2019. [CrossRef]

43. Sanagoo S, Oskouei BS, Abdollahi NG, Salehi-Pourmehr H, Hazhir N, Farshbaf-Khalili A. Effect of Tribulus terrestris L. on sperm parameters in men with idiopathic infertility: A systematic review. Complement Ther Med 2019;42:95-103. [CrossRef]

44. Fata S, Tokat M, Bagardi N, Yilmaz B. The traditional practices used by couples with fertility problems, affecting factors, expected benefits, and learning paths: The Turkey Sample. Niger J Clin Pract 2019;22:806. [CrossRef]
45. Salgado R, Marques-Silva M, Gonçalves E, Mathias A, Aguiar J, Wolff P. Effect of oral administration of Tribulus terrestris extract on semen quality and body fat index of infertile men. Andrologia 2017;49:e12655. [CrossRef]

46. Ahmad MK, Mahdi AA, Shukla KK, Islam N, Jaiswar SP, Ahmad $S$. Effect of Mucuna pruriens on semen profile and biochemical parameters in seminal plasma of infertile men. Fertil Steril 2008;90:627-35. [CrossRef]

47. Shukla KK, Mahdi AA, Ahmad MK, Shankhwar SN, Rajender S, Jaiswar SP. Mucuna pruriens improves male fertility by its action on the hypothalamus-pituitary-gonadal axis. Fertil Steril 2009;92:1934-40. [CrossRef]

48. Foresta C, Selice R, Garolla A, Ferlin A. Follicle-stimulating hormone treatment of male infertility. Curr Opin Urol 2008;18:602-7. [CrossRef]

49. Cooke HJ, Saunders PT. Mouse models of male infertility. Nat Rev Genet 2002;3:790-801. [CrossRef]

50. Ahmad MK, Mahdi AA, Shukla KK, Islam N, Rajender S, Madhukar $\mathrm{D}$, et al. Withania somnifera improves semen quality by regulating reproductive hormone levels and oxidative stress in seminal plasma of infertile males. Fertil Steril 2010;94:989-96. [CrossRef]

51. Santos HO, Howell S, Teixeira FJ. Beyond tribulus (Tribulus terrestris L.): The effects of phytotherapics on testosterone, sperm and prostate parameters. J Ethnopharmacol 2019;235:392-405. [CrossRef]

52. Aghaei S, Nikzad H, Taghizadeh M, Tameh A, Taherian A, Moravveji A. Protective effect of pumpkin seed extract on sperm characteristics, biochemical parameters and epididymal histology in adult male rats treated with cyclophosphamide. Andrologia 2014;46:927-35. [CrossRef]

53. Banihani SA. Effect of ibuprofen on semen quality. Andrologia 2019;51:e13228. [CrossRef]

54. Yüce A, Türk G, Çeribaşi S, Sönmez M, Çiftci M, Güvenç $M$. Effects of cinnamon (C innamomum zeylanicum) bark oil on testicular antioxidant values, apoptotic germ cell and sperm quality. Andrologia 2013;45:248-55. [CrossRef]

55. Kolahdooz M, Nasri S, Modarres SZ, Kianbakht S, Huseini HF. Effects of Nigella sativa L. seed oil on abnormal semen quality in infertile men: a randomized, double-blind, placebo-controlled clinical trial. Phytomedicine 2014;21:901-5. [CrossRef]

56. Khani B, Bidgoli SR, Moattar F, Hassani H. Effect of sesame on sperm quality of infertile men. J Res Med Sci 2013;18:184-7. https://pubmed.ncbi.nlm.nih.gov/23930112/

57. Dattilo M, Cornet D, Amar E, Cohen M, Menezo Y. The importance of the one carbon cycle nutritional support in human male fertility: a preliminary clinical report. Reprod Biol Endocrinol 2014;12:71. [CrossRef]

58. Miner SA, Robins S, Zhu YJ, Keeren K, Gu V, Read SC, Zelkowitz P. Evidence for the use of complementary and alternative medicines during fertility treatment: a scoping review. BMC Complement Altern Med 2018;18:1-12. [CrossRef]

59. You F, Ruan L, Zeng L, Zhang Y. Efficacy and safety of acupuncture for the treatment of oligoasthenozoospermia: A systematic review. Andrologia 2020;52:e13415. [CrossRef] 